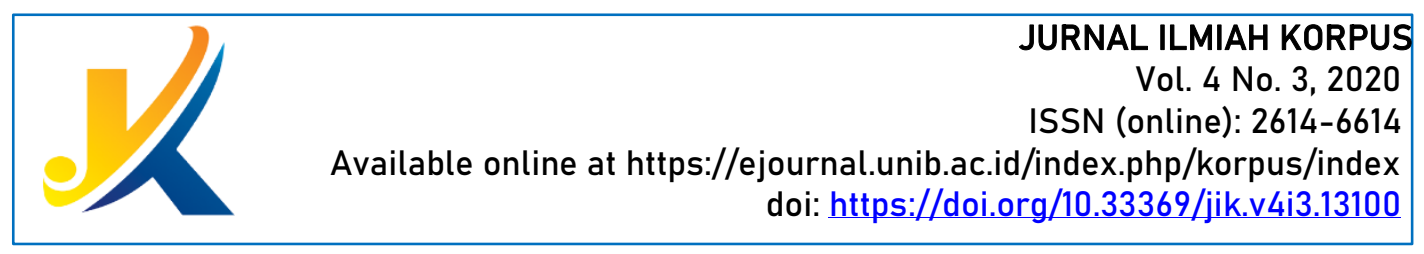

\title{
KESULITAN MENULIS TEKS EKSPLANASI SISWA KELAS VIISMPNEGERI 14 KOTA BENGKULU
}

\author{
'Else Puspita Sari, ${ }^{2}$ Agus Trianto, ${ }^{3}$ Padi Utomo \\ ${ }^{1,2,3}$ Program Studi Pendidikan Bahasa Indonesia Fakultas Keguruan dan Ilmu \\ Pendidikan
}

Korespondensi: elsepuspita56@gmail.com

\begin{abstract}
Abstrak
Tujuan penelitian untuk mengetahui kesulitan siswa dalam menulis teks eksplanasi siswa kelas VII SMP Negeri 14 Kota Bengkulu. Metode yang digunakan pada penelitian ini yaitu deskriptif kuantitatif. Berdasarkan hasil penelitian kesulitan menulis teks eksplanasi yaitu kesulitan menulis dari faktor internal, faktor eksternal, struktur dan kaidah kebahasaan. Kesulitan yang paling banyak dihadapi siswa dari segi faktor internal yaitu menentukan topik yang menarik 78,8\%. Kesulitan dominan dihadapi oleh siswa dari segi faktor eksternal yakni berhubungan dengan waktu pembelajran sebesar 58,3\%. Kesulitan menulis teks eksplanasi paling banyak dihadapi oleh siswa pada struktur teks eksplanasi yakni membedakan batasan umum dan deret penjelas (batasan antara pernyataan sebab dan akibat) sebesar 69,2\%. Kesulitan menulis teks eksplanasi paling banyak dihadapi oleh siswa pada penggunaan kaidah kebahasaan teks eksplanasi pada bidang keilmuan khusus sebesar $63,5 \%$.
\end{abstract}

Kata Kunci: Kesulitan Menulis, Teks Ekesplansi

Abstract

The research objective was to determine the difficulties of students in writing explanatory text for seventh grade students of SMP Negeri 14 Bengkulu City. The method used in this research is descriptive quantitative. Based on the research results, the difficulty in writing explanatory text is the difficulty of writing from internal factors, external factors, structure and language rules. The difficulty most students face in terms of internal factors is determining topics of interest to $78.8 \%$. The dominant difficulty faced by students in terms of external factors is related to the learning time of $58.3 \%$. The difficulty of writing explanatory text was mostly faced by students in the structure of the explanatory text, namely distinguishing general boundaries and explanatory series (boundaries between cause and effect statements) of $69.2 \%$. The difficulty of writing explanatory text was mostly faced by students in the use of explanatory text language rules in special scientific fields of $63.5 \%$.

Keywords: Writing Difficulty, Explanatory Text

\section{PENDAHULUAN}

Kompetensi dalam berbahasa itu sendiri terdiri dari empat aspek berbahasa, yaitu keterampilan menyimak, keterampilan berbicara, keterampilan membaca dan 
keterampilan menulis. Menurut Wassid (2008: 83), dibandingkan dengan tiga kemampuan berbahasa yang lain, kemampuan menulis lebih sulit dikuasai. Hal ini disebabkan kemampuan menulis menghendaki penguasaan berbagai unsur kebahasaan dan unsur diluar bahasa itu sendiri yang akan menjadi isi tulisan.

Kurikulum 2013 menekankan pembelajaran berbasis teks ini, siswa diharapkan mampu memproduksi (menulis) dan menggunakan teks sesuai dengan tujuan dan fungsi sosialnya. Salah satunya teks eksplanasi. Mahsun (2014: 94), pembelajaran bahasa Indonesia pada kurikulum 2013 diorientasikan pada pembelajaran berbasis teks. Pembelajaran bahasa Indonesia berbasis teks memberikan ruang kepada siswa untuk mengembangkan berbagai jenis struktur berpikir karena setiap teks memiliki struktur berpikir yang berbeda. Akan tetapi tidak semua orang memiliki keterampilan menulis dengan baik karena hampir sebagian orang masih mengalami kesulitan dalam menulis. Dalam hal ini teks yaitu teks eksplanasi. Karena teks eksplanasi merupakan teks yang baru dipelajari semenjak diterapkannya kurikulum 2013 sehingga siswa masih banyak kesulitan dalam memahami dan menulis teks ini.

Menurut Priyatni (2014: 37), teks dimaknai sebagai ujaran atau tulisan yang bermakna, yang memuat gagasan yang utuh. Menciptakan atau menyusun teks untuk tujuan tertentu, berarti melakukan pemilihan bentuk dan struktur teks yang digunakan agar pesan tersampaikan secara tepat. Teks wujudnya dapat berupa bahasa yang dituturkan, dituliskan, dan bentuk sarana lain yang digunakan untuk menyatakan pikiran. Teks memiliki struktur tersendiri setiap teks. Tujuan sosial yang akan dicapai manusia beragam, akan memunculkan teks atau struktur berpikir yang beragam.

Teks dalam kurikulum 2013 menjadi rumusan dari formula aktif untuk menyejajarkan pelaksanaan pendekatan ilmiah (pendekatan saintifik) sebagai teman sejati dalam kurikulum 2013. Menurut Priyatni (2014: 37), dalam kurikulum 2013 bahasa Indonesia tidak hanya difungsikan sebagai alat komunikasi, tetapi juga sebagai sarana berpikir. Bahasa adalah sarana untuk mengekspresikan gagasan dan sebuah gagasan yang utuh biasanya direalisasikan dalam bentuk teks. Dengan asumsi tersebut, fungsi pembelajaran bahasa adalah mengembangkan kemampuan memahami dan menciptakan teks karena komunikasi terjadi dalam teks inilah yang digunakan sebagai dasar pengembangan kompetensi dasar mata pelajaran bahasa Indonesia rana pengetahuan dan keterampilan dalam kurikulum 2013. Teks yang diformulasikan ke dalam pembelajaran bahasa Indonesia sebagai pengejawatan dari sistem budaya, sistem sosial, sistem kepribadian, dan sistem tingkah laku yang berlaku di masyarakat.

Teks dijadikan basis pembelajaran bahasa Indonesia dalam kurikulum 2013, dikarenakan ada beberapa alasan yang dikemukakan oleh Mahsun (2014: 97), yaitu: (1) melalui teks kemampuan berpikir siswa dikembangkan, (2) materi pembelajaran berupa teks lebih relevan dengan karakteristik kurikulum 2013 yang menetapkan capaian kompetensi siswa yang mencakupi ketiga ranah pendidikan: sikap, pengetahuan, dan keterampilan. Menurut Priyatni (2017: 32), Priyatni (2017: 32), teks yang dipelajari di kelas VII SMP/MTS teks hasil observasi, tanggapan deskriptif, eksposisi, eksplanasi, cerpen. Beberapa tahapan dalam pembelajaran teks diantaranya: (1) tahap pemodelan (percontohan), (2) tahap bekerja sama, (3) tahap membangun/mengembangkan teks secara mandiri. (Mahsun, 2014)

Teks eksplanasi menurut Priyatni (2014: 33), adalah teks yang memiliki fungsi sosial menjelaskan atau menganalisis proses muncul atau terjadinya sesuatu. Trianto 


\section{Else Puspita Sari}

(2020), menjelasakan bahwa teks eksplanasi merupakan tipe teks yang menjelaskan mengapa/bagaimana dalam artikel tulisan, pidato/ceramah, ilmiah(popular) dan surat tugas Menurut Mahsun (2014: 189), teks ini memiliki struktur berpikir pernyataan umum (pembukaan), deretan penjelas (isi), dan interpretasi (penutup). Sama hal dengan teks yang lain teks eksplanasi juga memiliki ciri dan karakteristik. Menurut Priyatni (2014: 85), ciri teks eksplanasi diantaranya: (1) memuat istilah, (2) struktur kalimatnya menggunakan kata sambung yang menunjukkan hubungan sebab akibat, (3) menjelaskan kondisi (menjelaskan fenomena bukan menceritakan masa lalu), (4) penggunaan konjungsi urutan/sekuen.

Menurut Suherly (2017: 83), ciri kebahasaan teks eksplanasi ada dua yaitu konjungsi kausalitas dan konjungsi kronologis. Konjungsi Kausalitas yaitu sebab, karena, oleh karena itu, oleh sebab itu dan sehingga. Konjungsi yang termasuk konjungsi kronologis yaitu, kemudian, lalu, setelah itu, dan pada akhirnya. Sedangkan menurut Kosasih (2016: 99), ciri kaidah penulisan teks eksplanasi diantaranya: (1) Menggunakan kalimat pasif, ditandai dengan kata kerja berawalan di- dan ter-, misalnya dibentuk dan terjadi (2) Menggunakan konjungsi sebab akibat, misalnya karena, dan disebabkan (3) menggunakan istilah-istilah keilmuan khusus misalnya sampel, (4) menggunakan bidang keilmuan (5) konjungsi kronologis yaitu, kemudian, lalu, setelah itu, dan pada akhirnya.

Menurut Abdurrahman (2003: 67), kesulitan merupakan terjemahan dari istilah bahasa Inggris disability. Disability artinya ketidakmampuan. Susetyo (2009: 1), menulis didefinisikan suatu keterampilan berbahasa menyampaikan pikiran yang berupa informasi dengan media tulis. Kesulitan menulis merupakan ketidakmampuan seseorang dalam menuangkan pikiran, ide dan gagasannya menjadi tulisan. Kesulitan dalam menulis yang dialami oleh siswa baik itu disebabkan oleh faktor yang ada dalam diri siswa maupun faktor dari guru dalam memberikan materi pembelajaran pada siswa di sekolah. Akibat kesulitan menulis yang dialami siswa, hampir keseluruhan siswa dalam mengerjakan tugas menulis teks eksplanasi mengambil tulisan orang lain yang ada di internet dan kadang tidak mengubah sedikit pun tulisan tersebut. Saputra (2019)

Beberapa kesulitan menulis menurut Darmadi (1996: 14), adapun hal yang menyebabkan siswa kesulitan dalam menulis, dapat digolongkan ke dalam dua faktor yaitu, faktor internal dan faktor eksternal. Faktor internal yang terdiri dari kesulitan untuk memulai tulisan, kesulitan menentukan topik tulisan, kesulitan menentukan ide, kesulitan menggunakan kosakata, kesulitan dalam menggunakan istilah, kesulitan membuat kalimat yang koheren, kesulitan dalam berlogika, tingkat kecerdasan yang kurang, lemah dalam menginterpretasikan kata, Pengalaman membaca yang sedikit. Sedangkan pada faktor eksternal yakni sering mendapatkan kritik dari orang lain, tulisannya sering ditertawakan, tidak adanya dukungan orang terdekat, sarana dan prasarana yang kurang mendukung.

Berdasarkan wawancara dengan guru di sekolah hasil belajar menulis teks eksplanasi siswa masih dikategorikan rendah. Hal ini dapat dilihat dari nilai hasil belajar menulis teks eksplanasi siswa, hampir setengah dari jumlah keseluruhan siswa belum mencapi kriteria ketuntasan minimal (70). Sebesar 42,9 \% siswa kelas 7 di SMP N 14 Kota Bengkulu belum memenuhi nilai minimal. Rendahnya hasil belajar menulis teks eksplanasi siswa inilah yang dapat menjadi asumsi bahwa adanya kesulitan yang dihadapi siswa dalam menulis dalam hal ini menulis teks eksplanasi di SMP Negeri 14 Kota Bengkulu. Adanya penelitian ini, diharapkan dapat mengungkap kesulitan siswa dalam menulis teks eksplanasi. 


\section{METODE}

Metode yang digunakan dalam penelitian ini adalah metode deskriptif dengan pendekatan kuantitatif. Penelitian ini dilaksanakan di SMP Negeri 14 Kota Bengkulu secara online melalui Aplikasi google form. Link kuesioner https://forms.gle/tvxtdchbUEJiApe27 dikirim secara online ke grup kelas VII SMP Negeri 14 Kota Bengkulu melalui Whats $A p p$, dimulai tanggal 5 sampai dengan 16 Juli 2020.

Teknik pengumpulan data yang digunakan dalam penelitian ini yaitu teknik kuesioner. Kuesioner dalam penelitian ini dengan bentuk pertanyaan terbuka. Bentuk pertanyaannya yaitu peneliti membuat pertanyaan dengan adanya alternatif jawaban lain hal ini dilakukan karena nantinya dimungkinkan responden memberikan jawaban yang berbeda dari jawaban yang telah di berikan oleh peneliti. Instrumen yang digunakan pada penelitian ini yaitu kisi-kisi kuesioner kesulitan dalam menulis teks eksplanasi.

Teknik analisis data yang digunakan dalam penelitian ini dengan langkah-langkah berikut: (1) Mengumpulkan Data, mengumpulkan data subjek penelitian dilakukan secara online dengan menggunakan aplikasi google form. Kemudian link kuesioner bttps://forms.gle/tvxtdchbUEJiApe27 dikirim melalui via WhatsApp. (2) Menghitung Persentase Hasil penjumlahan skor dihitung dengan menggunakan rumus $\mathrm{P}=\frac{x}{y} \times 100 \%$. (3)Menganalisis Data, dilakukan secara statistik deskriptif sederhana yaitu dengan menghitung persentase kesulitan menulis teks eksplanasi siswa SMP Negeri 14 Kota Bengkulu yang selanjutnya disajikan dalam bentuk diagram. kemudian dideskripsikan sesuai dengan hasil interpretasi data. Selanjutnya menyimpulkan hasil penelitian.

\section{HASIL DAN PEMBAHASAN}

Saat menulis teks eksplanasi siswa masih mengalami kesulitan, ketika ingin memulai menulis teks eksplanasi yaitu memulai dari mana tulisan akan di mulai sebanyak 10 jawaban dengan persentase sebesar 15,4\%, menentukan gagasan yang menarik untuk dituliskan sebanyak 9 jawaban dengan persentase sebesar 17,3\%, menentukan ide yang akan di tuliskan sebanyak 13 jawaban dengan persentase sebesar $25 \%$, menentukan topik yang ingin ditulis sebanyak 18 jawaban dengan persentase sebesar 34,6\%. Kemudian siswa juga masih mengalami kesulitan dalam menentukan topik tulisan teks eksplanasi yaitu memilih topik yang menarik sebanyak 41 jawaban dengan persentase sebesar 78,8\%, mencari bahan referensi untuk menentukan topik sebanyak 8 jawaban dengan persentase sebesar 15,4\%, memfokuskan topik yang ingin ditulis sebanyak 2 jawaban dengan persentase sebesar $3,81 \%$, pengalaman membaca yang sedikit sebanyak 1 orang dengan persentase sebesar $1,9 \%$.

Beberapa kesukaran yang siswa alami saat menulis teks eksplanasi ketika menggunakan ejaan bahasa Indonesia yang benar dalam menulis teks eksplanasi adalah penggunaan kata baku dan tidak baku sebanyak 26 jawaban dengan persentase sebesar $50 \%$, penggunaan kata ulang sebanyak 9 jawaban dengan persentase sebesar $17,3 \%$, penggunaan huruf kapital sebanyak 8 jawaban dengan persentase 15,4\%, penggunaan kata berimbuhan $7,7 \%$ dan penggunaan kata ganti sebanyak 2 jawaban dengan persentase sebesar 3,8\%. Bukan hanya penggunaan ejaan bahasa Indonesia yang benar tetapi siswa juga masih mengalami kesulitan penggunaan kaidah kebahasaan dalam menulis teks eksplanasi, siswa masih mengalami kesulitan yaitu pada penggunaan konjungsi kausalitas sebanyak 19 jawaban dengan persentase sebesar 36,5\%, penggunaan konjungsi 


\section{Else Puspita Sari}

kronologis sebanyak 18 dengan persentase sebesar 34,6\%, menggunakan istilah-istilah keilmuan khusus sebanyak 13 jawaban dengan persentase $25 \%$.

Menentukan ide yang menarik dalam menulis teks eksplanasi, siswa masih mengalami kesulitan dikarenakan pengalaman membaca yang kurang sebanyak 32,7\%, merasa ide yang akan ditulis tidak menarik sebanyak 32,7\%. Selain dalam menentukan ide yang menarik siswa juga masih mengalami kesulitan dalam penggunaan kosakata yaitu memilah kosakata menarik sebanyak 21 jawaban dengan persentase 40,4\%, penggunaan kosakata baku dan tidak baku sebanyak 18 jawaban dengan persentase sebesar 34,6\% Kemudian menggunakan kosakata tepat dalam kalimat sebanyak 13 jawaban dengan persentase sebesar $25 \%$. Sedangkan kesulitan yang dihadapi siswa dalam menulis teks eksplanasi pada penggunaan tanda baca adalah penggunaan tanda penghubung sebanyak 26 jawaban dengan persentase sebesar 50\%, penggunaan tanda koma sebanyak 13 jawaban dengan persentase sebesar 25\%, penggunaan tanda titik sebanyak 8 jawaban dengan persentase sebesar 15,8\%. Sedangkan pada penggunaan istilah siswa mengalami kesulitan yaitu penggunaan istilah sosiologi (sosial) siswa mengalami kesulitan sebanyak 22 jawaban dengan persentase sebesar 42,3\%, menggunakan kata dasar peristilahan sebanyak 15 jawaban dengan persentase $28,8 \%$ dan penggunaan istilah khusus sebanyak 14 jawaban dengan persentase sebesar $26,9 \%$.

Siswa masih mengalami kesulitan dalam menentukan judul yaitu menentukan judul yang menarik sebanyak 21 jawaban dengan persentase sebesar 40,4\%, judul yang topiknya sudah ditentukan oleh guru kurang di pahami sebanyak 20 jawaban dengan persentase sebesar 38,5\%, sulit menentukan judul karena kurang membaca sebanyak 8 jawaban dengan persentase sebesar 15,4\%. Selain itu siswa juga masih kesulitan dalam menulis teks eksplanasi sesuai dengan struktur teks eksplanasi adalah menyatakan deretan penjelas sebanyak 19 jawaban dengan persentase sebesar 36,5\%, menyatakan pendapat dalam penutup/kesimpulan sebanyak 17 jawaban dengan persentase sebesar 32,7\%, menyatakan pernyataan umum sebanyak 15 jawaban dengan persentase 28,8\%, membedakan batasan pernyataan umum dan deretan penjelas sebanyak 36 jawaban dengan persentase sebesar $69,2 \%$, mengetahui batasan paragraf pada pernyataan umum sebanyak 16 jawaban dengan persentase sebesar 30,8\%. Sedangkan kesulitan yang dihadapi siswa pada penggunaan preposisi adalah menentukan penggunaan di dapat dipisahkan atau digabungkan sebanyak 19 jawaban dengan persentase sebesar 36,5\%, menentukan penggunaan ke dapat dipisahkan atau digabungkan sebanyak 17 jawaban dengan persentase sebesar 32,7\%, penggunaan kata di, ke dan dari tulisan sebanyak 15 jawaban dengan persentase sebesar $28,8 \%$.

Penggunaan konjungsi kausalitas dalam menulis teks eksplanasi merupakan hal yang menjadi kesulitan siswa dalam menulis teks eksplanasi, yaitu siswa sulit memilih konjungsi yang tepat sebanyak 21 dengan persentase sebesar 40,4\%, penggunaan konjungsi pada bagian kalimat maupun paragraf sebanyak 16 jawaban dengan persentase sebesar 30,8\%, dan penggunaan konjungsi karena tidak memahami sebanyak 14 jawaban dengan persentase sebesar 26,9\%. Selanjutnya siswa juga mengalami kesulitan dalam menulis teks eksplanasi pada menjabarkan deretan penjelas yaitu mendapatkan data fakta untuk mendukung pendapat awal sebanyak 18 jawaban 34,6\%, menjabarkan deretan penjelas pada menambahkan informasi pendukung untuk menambah keyakinan pembaca atas tulisan dan mengembangkan ide pada pendapat awal (dalam pernyataan umum) seimbang dengan jawaban masing-masing jawaban sebanyak 17 jawaban dengan 
persentase 32,7\%. Selain kesulitan itu siswa juga mengalami kesulitan saat menentukan batasan deretan penjelas dengan penutup adalah membedakan batasan deretan penjelas dan penutup sebanyak 33 jawaban dengan persentase $63,5 \%$ dan mengetahui batasan paragraf pada deretan penjelas sebanyak 18 jawaban dengan persentase sebesar 34,6\%. Namun pada penggunaan istilah keilmuan khusus dalam menulis teks eksplanasi siswa mengalami kesulitan yang terdiri dari tidak memiliki semata yang luas mengenai topik yang ditulis sebanyak 22 jawaban dengan persentase sebesar 42,3\%, tidak mengerti keilmuan khusus yang berhubungan dengan teks yang ditulis sebanyak 17 jawaban dengan persentase sebesar 32,7\% dan tidak mengetahui kapan dan di bagian mana keilmuan khusus digunakan sebanyak 12 jawaban dengan persentase sebesar 23,1\%.

Bidang keilmuan tertentu dalam teks eksplanasi ternyata menjadi hal yang sulit dalam siswa menulis teks eksplanasi yaitu dikarenakan siswa mengetahui sedikit bidang keilmuan sosiologi tapi sulit untuk pengaplikasian dalam teks eksplanasi sebanyak 33 jawaban dengan besar persentase $63,5 \%$, tidak mengetahui sama sekali bidang keilmuan sosiologi sebanyak 18 jawaban dengan persentase sebesar 36,4\%. Namun kesulitan yang lain yang siswa hadapi dalam menulis teks eksplanasi pada bagian struktur penutup/simpulan adalah mengemukakan pendapat terhadap yang telah disampaikan sebanyak 29 jawaban dengan persentase sebesar 55,8\% dan membuat kesimpulan sebanyak 19 jawaban dengan jumlah persentase sebesar 36,5\%. Selanjutnya siswa juga masih mengalami kesulitan dalam mengondisikan diri dengan emosional kritikan teman sebanyak 20 jawaban dengan persentase sebesar 38,5\%., selalu mendapat kritik dari teman yang tidak membangun sebanyak 19 jawaban dengan persentase sebesar 36,5\% dan takut memulai karena ditertawakan tulisan tidak sesuai sebanyak 12 jawaban dengan persentase sebesar $23,1 \%$.

Media pembelajaran turut serta berpengaruh pada siswa dalam menulis teks eksplanasi yaitu siswa sulit mencari referensi yang akan digunakan saat menulis sebanyak 19 jawaban dengan persentase sebesar 36,5\%, mencocokkan pendapat dengan ketersediaannya referensi yang minim sebanyak 16 jawaban dengan persentase sebesar $30,8 \%$ dan media pembelajaran yang tidak sesuai dengan materi sebanyak 15 jawaban dengan persentase sebesar $28,8 \%$. Selain pada media pembelajaran siswa mengalami kesulitan dalam membagi waktu antara organisasi sekolah dan menulis sehingga tidak mengerti menulis teks eksplanasi sebanyak 19 jawaban dengan besar persentase sebesar 36,5\%, kemudian minat mengikuti pembelajaran teks eksplanasi sebanyak 17 jawaban dengan persentase sebesar $32,7 \%$, metode dalam menyampaikan pembelajaran kurang jelas sebanyak 10 jawaban dengan persentase sebesar 19,2\% bahan ajar guru yang terlalu banyak sebanyak 5 jawaban dengan besar persentase 9,6\%.

Waktu pembelajaran dalam belajar teks eksplanasi juga mempengaruhi siswa dalam menulis teks eksplanasi yaitu siswa tidak memahami teks eksplanasi karena waktu yang digunakan guru dalam menjelaskan terbatas sebanyak 28 jawaban dengan persentase sebesar $58,3 \%$, siswa tidak mendapatkan kesempatan bertanya pada saat pembelajaran teks eksplanasi sehingga tidak terjawab hal yang belum di mengerti sebanyak 20 jawaban dengan persentase $38,5 \%$. Selanjutnya siswa juga mengalami kesulitan saat akan memulai menulis teks eksplanasi berhubungan dengan proses pembelajaran adalah kurangnya minat terhadap pembelajaran sebanyak 25 jawaban dengan persentase sebesar 48,1\%, kurangnya waktu terhadap pembelajaran sebanyak 16 jawaban dengan persentase sebesar $30,8 \%$, tidak memahami pembelajaran sebanyak 9 jawaban dengan persentase sebesar 


\section{Else Puspita Sari}

17,3\%. Kemudian kesulitan yang dihadapi saat ingin menulis teks eksplanasi adalah mendapatkan kritik dari orang lain akut di kritik teman yang tidak bersifat membangun (ejekan) sebanyak 26 jawaban dengan persentase sebesar 50\%, takut dikritik tulisan tidak baik sebanyak 16 jawaban dengan persentase sebesar 30,8\%, tulisan sering ditertawakan sebanyak 5 jawaban dengan persentase sebesar 9,6\%.

Berdasarkan penelitian yang telah dilakukan diperoleh informasi kesulitan menulis dari faktor internal, eksternal, struktur dan kaidah kebahasaan yang dialami siswa dalam menulis teks eksplanasi.

\section{A. Faktor Internal}

Faktor internal merupakan faktor utama dalam diri siswa yang menjadi kesulitan siswa dalam menulis. Faktor ini sering juga disebut sebagai faktor internal dalam tahapan menulis. Kesulitan menulis internal tersebut dilihat dari segi aspek pemahaman siswa terhadap menulis dan dilihat dari segi aspek struktur teks eksplanasi itu sendiri. Ada banyak kesulitan internal dilihat dari segi aspek pemahaman siswa seperti tanda baca, penggunaan ejaan, menentukan judul, dalam menggunakan istilah, memilih ide yang menarik, menentukan topik, pemilihan kosa kata, penggunaan preposisi.

Faktor dari kesulitan internal yang dialami siswa dari segi aspek pemahaman pada menentukan judul 40,4\%, menentukan topik sebesar 78,8\%, tanda baca sebesar 50\%, penggunaan ejaan sebesar $50 \%$, memilih ide yang menarik $32,7 \%$, pemilihan kosa kata yang tepat dalam kalimat 40,4\% dan penggunaan preposisi sebesar 36,5\%. Menentukan topik tulisan merupakan faktor kesulitan yang paling dominan dihadapi siswa dari segi faktor internal yaitu menentukan topik yang menarik 78,8\%. Hal ini disebabkan oleh beberapa hal diantaranya siswa membaca dan siswa memiliki pengetahuan yang sangat terbatas mengenai topik-topik yang akan ditulis. Topik tulisan akan muncul dan mudah didapat ketika siswa sudah banyak membaca. Sejalan dengan Darmadi (1996: 14) kesulitan dalam menentukan ide dan topik penyebabnya salah satunya adalah pengalaman membaca yang sedikit. Pengalaman membaca yang sedikit akan sulit mendapatkan wawasan dalam menulis sedangkan menulis membutuhkan wawasan dan pengetahuan yang luas. Sedangkan kesulitan yang paling sedikit dihadapi siswa dalam menulis dilihat dari segi faktor internal yaitu pada penggunaan preposisi sebesar 36,5\%, kesulitan ini paling sedikit dialami siswa jika dilihat dari segi faktor internal menulis karena siswa sebagian telah memahami penggunaan preposisi yang benar saat menulis walaupun masih ada siswa yang belum memahami penggunaan preposisi dalam menulis hal ini dikarenakan siswa salah dalam membedakan antara di sebagai preposisi (kata depan) dan di sebagai Prefiks atau (imbuhan).

A. Faktor Eksternal

Faktor eksternal menulis atau yang juga disebut faktor yang berasal dari luar siswa itu sendiri, orang terdekat maupun sarana dan prasarana yang kurang mendukung. Beberapa faktor yang kesulitan menulis eksternal yaitu sering mendapatkan kritik dari orang lain, tulisannya sering ditertawakan, waktu dalam pembelajaran, media pembelajaran, dan metode pembelajaran. Faktor dari kesulitan eksternal yaitu mendapatkan kritik yang tidak membangun atau bersifat ejekan, mengondisikan emosional dari kritik teman 50\%, tulisannya sering ditertawakan sebesar 9,6\%, media pembelajaran sebesar 36,5\%, dan metode pembelajaran kurangnya pembelajaran waktu dalam pembelajaran kurang sehingga tidak memahami pembelajaran sebesar 58,3\%. Kesulitan yang dominan dihadapi oleh siswa dari segi faktor eksternal yakni berhubungan 
dengan waktu yang digunakan guru dalam menjelaskan terbatas sebesar 58,3\%. Kurangnya waktu dalam belajar mengakibatkan siswa tidak bisa memahami dengan jelas struktur yang tepat dari teks eksplanasi. Akhirnya siswa belum secara maksimal memahami teks eksplanasi. Faktor ini bisa diminimalisir oleh siswa. Siswa dapat membaca lagi materi untuk menambah penjelasan dari guru, yang informasi materi dapat dicari perpustakaan dan media elektronik internet. Sejalan dengan yang dikatakan oleh Hamalik (1990), Kesulitan belajar siswa bukan hanya berasal dari diri sendiri melainkan dari beberapa faktor yang berasal dari lingkungan sekolah. Adapun faktor-faktor yang disebabkan dari sekolah diantaranya: (1) cara guru memberikan pelajaran, (2) kurangnya bahan bacaan guru mengajar, (3) kurangnya sarana dan prasarana dalam mengajar, (4) bahan pelajaran tidak sesuai dengan kemampuan.

Kesulitan menulis dari segi faktor eksternal yang paling sedikit dihadapi siswa yaitu tulisannya sering ditertawakan sebesar 9,6\%, tulisan yang ditertawakan teman sebagai bentuk penolakan terhadap tulisan yang ditulis hal ini yang membuat siswa merasa pesimis dan tidak percaya diri untuk menulis. Sejalan dengan menurut, Darmadi (1996: 14), Kesulitan menulis yang disebabkan oleh faktor yang berasal dari luar siswa itu sendiri baik dari faktor orang terdekat maupun sarana dan prasarana yang kurang mendukung. diantaranya: sering mendapatkan kritik dari orang lain, tulisannya sering ditertawakan, tidak adanya dukungan orang terdekat, sarana dan prasarana yang kurang mendukung.

B. Struktur Teks Eksplanasi

Dilihat dari segi struktur teks eksplanasi kesulitan yang dihadapi siswa dalam menulis seperti, memilih judul yang tepat untuk menggambarkan isi teks, mengemukakan pendapat pada pernyataan umum, deretan penjelas, penutup/simpulan. Kesulitan menulis teks eksplanasi yang dialami oleh siswa yaitu kesulitan yang berkaitan dengan penulisan struktur teks eksplanasi yaitu, menentukan judul teks eksplanasi yang menarik sebesar 40,4\%, menuliskan fenomena penting pada struktur pernyataan umum (sebab) yang akan dituliskan sebesar 34,6\%, menuliskan fenomena yang berupa fakta pada deretan penjelas (akibat) sebesar 44,6\%, membedakan batas pernyataan umum dengan penjelas (sebab akibat) sebesar 69,2\%, membedakan batasan deret penjelas (akibat) dengan penutup sebesar $63,5 \%$ dan menuliskan pendapat (opini) pada kesimpulan sebesar 55,8\%. Pada struktur teks eksplanasi kesulitan yang paling dominan yaitu pada membedakan batas pernyataan umum dengan penjelas (sebab akibat) sebesar 69,2\%, kesulitan yang dihadapi dalam hal ini karena kan siswa belum memahami struktur teks eksplanasi yang tepat sehingga antara bagian pernyataan umum (sebab) dan bagian pernyataan penjelas (akibat) masih rancu sehingga siswa masih kesulitan dalam menuliskan batasannya tersebut. Sedangkan yang paling sedikit dihadapi siswa dalam menulis teks eksplanasi pada struktur teks yaitu pada pernyataan umum yang akan dituliskan sebesar 34,6\% dikarenakan siswa telah sebagian besar memahami isi dari pernyataan umum yang seperti apa yang harusnya ditulis pada pernyataan umum yang memuat fakta-fakta yang bersifat umum yang nantinya dikembangkan pada struktur selanjutnya yaitu deret penjelas. Struktur teks eksplanasi Priyatni (2014: 83) yakni judul, Pernyataan umum (sebab), penjelas (akibat), dan penutup (kesimpulan). Sejalan dengan itu siswa mesti mampu memahami terlebih dahulu teks eksplanasi, agar dapat menulis teks eksplanasi sesuai dengan struktur yang tepat pada teks tersebut.

Hal ini terjadi karena siswa banyak yang belum memahami struktur teks eksplanasi yang tepat. Pemahaman siswa yang kurang dalam memahami teks eksplanasi 


\section{Else Puspita Sari}

dapat disebabkan oleh kurangnya pengetahuan siswa mengenai teks eksplanasi diikuti dengan referensi bacaan siswa mengenai teks eksplanasi yang masih minim, serta siswa yang masih sulit memperoleh ide yang akan dituliskan ke dalam teks eksplanasi dikarenakan kurang membaca. Sementara bahan bacaan yang berupa teks eksplanasi dapat diperoleh secara mudah baik itu secara cetak maupun online (buku online) yang dapat dijadikan referensi untuk menulis teks eksplanasi. Sehingga untuk menulis struktur teks eksplanasi mulai dari menentukan judul sampai dengan kesimpulan dapat dilakukan dengan membaca. Oleh sebab itu hendaknya siswa sering membaca. Seperti dalam pendapat (Mawardi, 2009) pengetahuan, ide sangat mudah didapatkan terutama salah satunya adalah membaca.

C. Kaidah Kebahasaan Eksplanasi

Teks eksplanasi pada penulisannya memiliki kaidah kebahasaan tersendiri. Kaidah kebahasaan pada teks eksplanasi masih menjadi kesulitan siswa dalam menulis teks tersebut. Kesulitan menulis teks eksplanasi yang dialami oleh siswa, berkaitan pada penulisan kaidah kebahasaan teks eksplanasi yaitu kesulitan penggunaan kaidah kebahasaan teks eksplanasi pada konjungsi kronologis sebesar 34,6\%, konjungsi kausalitas sebesar 36,5\%, bidang istilah keilmuan sebesar 25\% sedangkan penggunaan kaidah kebahasaan teks eksplanasi pada bidang keilmuan tertentu sebesar 63,5\%. Pada penggunaan kaidah kebahasaan kesulitan yang paling dominan yakni penggunaan bidang keilmuan sebesar $63,5 \%$. Hal demikian terjadi dikarenakan siswa tidak mengetahui dan belum mengerti kaidah konsep kebahasaan teks eksplanasi. Sedangkan yang paling sedikit dihadapi siswa pada penggunaan kaidah kebahasaan yaitu penggunaan bidang istilah keilmuan sebesar 25\% karena sebagian siswa sudah memahami istilah keilmuan tersebut dan memang pada dasarnya siswa harus bisa memahami dan mengaplikasikannya saat menulis teks eksplanasi karena teks eksplanasi memiliki beberapa kaidah kebahasaan pada penggunaan kebahasaan teks eksplanasi yang seharusnya dapat dipahami oleh siswa, sebagaimana dalam Kosasih (2016: 99), diantaranya: (1) menggunakan kalimat pasif, kata kerja berawalan di- dan ter- (2) menggunakan konjungsi sebab akibat, (3) menggunakan istilah-istilah keilmuan khusus misalnya sampel, (4) menggunakan bidang keilmuan tertentu (5) konjungsi kronologis.

\section{PENUTUP}

Berdasarkan hasil penelitian dan pembahasan, dapat disimpulkan bahwa kesulitan menulis teks eksplanasi siswa kelas VII SMP Negeri 14 Kota Bengkulu yaitu kesulitan dari faktor internal, kesulitan dari faktor eksternal, kesulitan pada penulisan struktur teks eksplanasi dan kaidah kebahasaan teks eksplanasi. Kesulitan yang paling dominan dialami siswa dalam menulis teks eksplanasi baik itu dari faktor internal yakni menentukan topik yang menarik $78,8 \%$. Kesulitan eksternal paling banyak dihadapi oleh siswa yakni tidak memahami teks eksplanasi karena waktu yang digunakan guru dalam menjelaskan terbatas sebesar 58,3\%. Kesulitan yang paling dominan pada penggunaan kaidah kebahasaan yakni penggunaan bidang keilmuan sebesar 63,5\%. Kesulitan menulis teks eksplanasi pada struktur teks eksplanasi yang paling dominan yaitu pada membedakan batas pernyataan umum dengan penjelas (sebab akibat) sebesar 69,2\%. Jadi, jika dilihat dari kesulitan dominan yang dialami siswa saat menulis teks eksplanasi baik itu dari faktor internal, faktor eksternal, struktur maupun kaidah kebahasaan teks eksplanasi. Faktor 
utama yang mempengaruhi sulitnya siswa menulis teks eksplanasi dipengaruhi oleh faktor internal atau faktor yang ada dalam siswa itu sendiri.

Adapun saran sebagai berikut: Siswa hendaknya lebih rajin dan giat dalam membaca baik itu membaca pengetahuan alam, sosial, budaya, dan karya sastra. Hal ini bertujuan supaya menambah wawasan pengetahuan yang mumpuni untuk menulis teks apapun itu karena ide akan mudah didapat dengan seringnya membaca. Sehingga saat menulis teks eksplanasi akan mampu untuk menuliskan struktur teks yang tepat hingga menjadi sebuah tulisan yang baik. Selain itu siswa juga harus menyiasati keadaan jika waktu kurang dalam pembelajaran ada baiknya mencari sendiri karena di zaman sekarang informasi bisa diakses dimana saja dan kapan saja baik secara cetak maupun online.

Guru bisa meningkatkan keprofesionalan dalam mengajar di kelas, dapat menerapkan penggunaan media yang tepat dalam mengajar sehingga media yang digunakan dapat membantu siswa dalam memahami teks yang diajarkan salah satunya yaitu teks eksplanasi, selain itu guru juga dapat memanfaatkan waktu yang terbatas dalam mengajar. Karena cara mengajar akan berpengaruh dengan waktu proses kegiatan pembelajaran yang digunakan saat mengajar.

\section{DAFTAR PUSTAKA}

Abdurrahman, M. (2003). Pendidikan Bagi Anak Berkesulitan Belajar. Jakarta: Rineka Cipta.

Darmadi, K. (1996). Meningkatkean Kemampuan Menulis. Yogyakarta: ANDI.

Hamalik, O. (1990). Metode Belajar dan Kesulitan Belajar. Bandung: Tarsito.

Kosasih, E. (2016). Mandiri Bahasa Indonesia untuk SMP/MTS Kelas VII. Jakarta : Erlangga.

Mahsun. (2014). Teks dalam Pembelajaran Bahasa Indonesia. Jakarta: PT Raja Grafindo Persada.

Mawardi, dodi. (2009). Cara Mudah Menulis Buku. Jakarta: Raih Asa Sukses.

Priyatni, E. T. (2014). Desain Pembelajaran Bahasa Indonesia dalam Kurikulum 2013. Jakarta: PT Bumi Aksara.

Saputra, N. W. (2019). Kajian Teks Eksplanasi Siswa Kelas VIII SMP Negeri di Kota Bengkulu. Diksa Jurnal Pendidikan Babasa dan Sastra , 1. https://scholar.google.co.id/citations?user=chfV5LoAAAAJ\&hl=id Diakses Tanggal 28 Februari 2020

Suherly. (2017). Guru Guru Babasa Indonesia. Jakarta: Kemendikbud.

Susetyo. (2009). Menulis Akademik. Bengkulu: FKIP Universitas Bengkulu. 
Else Puspita Sari

Trianto, Agus. (2020). Genre, Tipe Teks Lokasi Sosial 2. Bengkulu: YouTube Agus Trianto Channel. https://youtu.be/0JTnw9KPoN0 Diakses Tangggal 14 September 2020

Wassid, I. (2008) Strategi Pembelajaran Bahasa. Bandung: PT Remaja Rosdakarya. 